\title{
Impact of Phosphorus and Sulphur Application on Yield, Phosphorus and Micronutrients Uptake by Wheat Plants \\ Ezzat M. Ahmed
}

Soil and Water Dept., Faculty of Agriculture, Assiut University, Assiut, Egypt.

Received on: 20/6/2016

Accepted for publication on: 23/6/2016

\section{Abstract}

A field experiment was carried out at the Experimental Farm Station of Soils and Water Department, Faculty of Agricultural, Assiut University, during 2013/2014 growth season to investigate the effect of application of phosphorus (P) and sulphur (S) on yield, and the uptake of phosphorus and some micronutrients by wheat plants. The treatments comprised of three P levels $(0,30,60 \mathrm{~kg}$ $\mathrm{P}_{2} \mathrm{O}_{5}$ fed $\left.^{-1}\right)$ and three $\mathrm{S}$ levels $\left(0,100,200 \mathrm{~kg} \mathrm{~S}^{-1} \mathrm{~d}^{-1}\right)$ in different combinations. Applications of $\mathrm{P}$ at 30 and $60 \mathrm{~kg} \mathrm{P}_{2} \mathrm{O}_{5}$ fed $^{-1}$ showed significant increases in the main straw yield of wheat of 4.45 to $10.50 \%$, respectively, over the control. Also, $\mathrm{S}$ addition at 100 and $200 \mathrm{~kg} \mathrm{~S}^{-1} \mathrm{de}^{-1}$ resulted in a significant increase in the main wheat straw yield of 1.51 and $3.11 \%$ over the control, respectively. Moreover, a respective significant increase in the main grain yield of 3.58 to $9.56 \%$ was observed due to application of the two P levels, but both applied S levels caused a respective significant increase in the main grain yield of 1.50 to $3.08 \%$ over the control. The application effect of both $\mathrm{P}$ and $\mathrm{S}$ was synergistic at all applied levels. Applying P at levels of 30 and $60 \mathrm{~kg} \mathrm{P}_{2} \mathrm{O}_{5} \mathrm{fed}^{-1}$ produced an increase in the main $P$ uptake of 23.19 and $54.23 \%$ by wheat straw, respectively, and 11.89 and $28.83 \%$ by wheat grains, respectively, over the control. Also, S applications caused similar effect on the main $\mathrm{P}$ uptake by both straw and grains. Moreover, the highest applied $\mathrm{P}$ level caused increases in main $\mathrm{Fe}, \mathrm{Zn}, \mathrm{Mn}$ and $\mathrm{Cu}$ uptakes of $43.32,48.65,36.37$ and $69.75 \%$, respectively, by the straw, respectively, and increases in main $\mathrm{Zn}, \mathrm{Mn}$ and $\mathrm{Cu}$ uptakes of $36.37,16.92$ and $75.02 \%$, respectively, by the grains over the control, and decreases in the Fe uptake of $1.63 \%$ by grain . In addition, the highest $\mathrm{S}$ applied level resulted in increases in the main uptake of $\mathrm{Fe}, \mathrm{Zn}, \mathrm{Mn}$ and $\mathrm{Cu}$ of 21.29, 22.52, 53.32 and $58.83 \%$, respectively, by the straw and $15.04,16.12,26.18$ and $28.16 \%$, respectively, by the grains over the control.

Keywords: Phosphorus: Sulphur; Wheat; Straw yield; Grain yield; Micronutrient uptake

\section{Introduction}

Wheat is the most important and widely cultivated crop of the entire world. It is the principal food for human beings in most countries. Egypt is one of these countries that depends on wheat as a food and consumes about 9 million ton/year.

Sulphur (S) interacts with phosphorus $(\mathrm{P})$ in the soils which the phosphate ion is more strongly bound to soil compounds than sulphate (Hedge and Murthy, 2005). Applications of phosphorus fertilizer increase the phosphate adsorption on soil constituents, which cause sulphate ions to release into soil solution (Tiwari and Gupta, 2006). Thus, sulphate ions may be subjected to leaching if they are not taken up by plant roots. The application of phosphorus was reported to cause a significant increase 
in wheat grain yield, and the highest grain yield was found to be related to the high level of soil phosphorus. (Shuaib et al., 2009).

Alam et al. (2003) indicted that the application of phosphorus fertilizer to wheat crop significantly increased the plant height, number of tillers per plant, straw and grain yields as well as the $\mathrm{P}$ uptake by grains over the control. A synergistic relationship exists between phosphorus and sulphur at the low applied level of sulphur to wheat (Randhawa and Arora, 2000). Hence, the nature of interaction of both nutrients depends up on the initial soil fertility status, the nutrient applied levels and the crop species.

Phosphorus and sulphur are known to interact with all essential macronutrients and micronutrients (Abdin et al, 2003). Additions of sulphur containing fertilizers may result in a soil acidification and eventually may have impacts on the uptake of other nutrients (Havlin et al, 2007). Also, a synergistic effect of both applied $\mathrm{S}$ and $\mathrm{Fe}$ was also reported by Malewar and Ismail (1997). The combined application of both nutrients resulted in a tremendous boost of $101 \%$ in $\mathrm{Fe}$ availability. A close relationship was observed between $\mathrm{Fe}$ and $\mathrm{S}$ in plant metabolism (Malewar and Ismail, 1997).

Tufemkci et al. (2005) showed that the soil application of phosphorus resulted in increases in the uptake of $\mathrm{Zn}, \mathrm{Cu}, \mathrm{Fe}$ and $\mathrm{Mn}$ by plant tissues. However, Bakhshipour et al. (2008) found that the P application at a range level of 0 to $35 \mathrm{mg} \mathrm{P} \mathrm{kg}{ }^{-1}$ caused a decrease in $\mathrm{Zn}$ concentration of tea seedlings.

The current study aimed to investigate the effects of both $\mathrm{P}$ and elemental $\mathrm{S}$ applications on yield and uptake of $\mathrm{P}, \mathrm{Fe}, \mathrm{Mn}, \mathrm{Zn}$ and $\mathrm{Cu}$ by wheat plants.

\section{Materials and Methods}

A field experiment was conducted at the Experimental Farm Station of Soils and water Department, Faculty of Agricultural, Assiut University, situated at a latitude of $27^{\circ}$, $11^{\prime} \mathrm{N}$, a longitude of $31^{\circ} 10^{\prime} \mathrm{E}$ and 52 $\mathrm{m}$ above the sea level during the winter growth season of 2013/2014 to study the effects of phosphorus and sulphur applications on the yield and uptakes of $\mathrm{P}, \mathrm{Fe}, \mathrm{Mn}, \mathrm{Zn}$ and $\mathrm{Cu}$ by wheat plants. Some soil physical and chemical properties of the experimental site are present in Table 1. 
Table 1. Some physical and chemical properties of a representative soil samples of the experimental site before sowing

\begin{tabular}{|c|c|}
\hline Particle - size distribution & \\
\hline Sand $(\%)$ & 24.20 \\
\hline Silt $\quad(\%)$ & 62.45 \\
\hline Clay $(\%)$ & 13.35 \\
\hline Texture grade & Silt loam \\
\hline $\mathrm{pH}(1: 1$ suspension $)$ & 7.66 \\
\hline EC $1: 1$ extract $\left(\mathrm{dS} \mathrm{m}^{-1}\right)$ & 1.07 \\
\hline Total $\mathrm{CaCO}_{3} \quad(\%)$ & 2.85 \\
\hline \multicolumn{2}{|l|}{ Soluble Ions $\left(\mathrm{mmol} \mathrm{kg}^{-1}\right)$} \\
\hline $\mathrm{Ca}^{++}$ & 4.75 \\
\hline $\mathrm{Mg}^{++}$ & 1.50 \\
\hline $\mathrm{Na}^{+}$ & 6.10 \\
\hline $\mathrm{K}^{+}$ & 1.03 \\
\hline $\mathrm{Cl}^{-}$ & 4.07 \\
\hline $\mathrm{HCO}_{3}^{-}$ & 7.01 \\
\hline $\mathrm{SO}_{4}=$ & 6.55 \\
\hline $\mathrm{NaHCO}_{3}$-extractable phosphours $\left(\mathrm{mg} \mathrm{Kg}^{-1}\right)$ & 15.55 \\
\hline DTPA-extractable Fe $\left(\mathrm{mg} \mathrm{Kg}^{-1}\right)$ & 4.52 \\
\hline DTPA-extractable $\mathrm{Mn} \quad\left(\mathrm{mg} \mathrm{Kg}^{-1}\right)$ & 12.20 \\
\hline DTPA-extractable $\mathrm{Zn} \quad\left(\mathrm{mg} \mathrm{Kg}^{-1}\right)$ & 0.45 \\
\hline DTPA-extractable $\mathrm{Cu} \quad\left(\mathrm{mg} \mathrm{Kg}^{-1}\right)$ & 0.65 \\
\hline
\end{tabular}

The trial was laid out in a randomized complete block design with a split plot $(3 \times 3.5 \mathrm{~m})$ arrangement. Phosphorus $(\mathrm{P})$ treatments were in the main plots whereas elemental sulphur (S) ones were in the subplots. There were nine treatments having different combinations including three levels of $\mathrm{P}\left(0,30,60 \mathrm{~kg} \mathrm{P}_{2} \mathrm{O}_{5} \mathrm{fed}^{-1}\right)$ and three levels of elemental S $(0,100$, $200 \mathrm{~S} \mathrm{~kg} \mathrm{fed}^{-1}$ ). Nitrogen was applied at the level of $75 \mathrm{~kg} \mathrm{~N}$ fed. ${ }^{-1}$ as urea $(46.5 \% \mathrm{~N})$ and potassium fertilizer was added at the level of $50 \mathrm{~kg} \mathrm{~K}_{2} \mathrm{O}$ fed. $^{-1}$ in the form of potassium sulphate $\left(48 \% \mathrm{~K}_{2} \mathrm{O}\right)$. Phosphorus treatments were used in the form of triple superphosphate $\left(40-48 \% \mathrm{P}_{2} \mathrm{O}_{5}\right)$. All treatments were replicated three times. The applied different combinations of $\mathrm{P}$ and $\mathrm{S}$ treatments are shown in Table (2).

Wheat (Sids 12) seeds were sown on Nov. 10, 2013. Phosphorus and sulphur treatments were applied before crop sowing. Crop was grown under surface irrigation. All agricultural practices were done as recommended for wheat crop. The preceding crop was maize. The crop was harvested on May 20, 2014. On that date an area of one square meter was selected in the middle of each plot and its plants were separately collected. The plant samples were dried and then grains and straw yield were recorded.

Representative $50 \mathrm{~g}$ samples of both straw and grains were separately collected from the bulk sample of each plot, oven- dried, ground and digested using the $\mathrm{H}_{2} \mathrm{SO}_{4}$ and $\mathrm{H}_{2} \mathrm{O}_{2}$ method that was described by Parkinson and Allen (1975). Phosphorus in the digests was determined by spectrophotometer. In addition, $\mathrm{Fe}, \mathrm{Zn}$, $\mathrm{Mn}$ and $\mathrm{Cu}$ in the plant digests were measured using the Inductivity 
Coupld Optical Emission Spectrometry (ICP-OES, thermo iCAP 6000 Series). The analysis of variance was carried out according to Gomez and Gomez (1984) using the MSTAT computer software. The means of the treatments were compared using the least significant difference (LSD) test at the 0.01 level of probability.

Table 2. Applied combinations treatments of phosphorus and sulphur.

\begin{tabular}{|l|c|c|}
\hline \multirow{2}{*}{ Treatment } & \multicolumn{2}{|c|}{ Applied level $\left(\mathbf{k g ~ f e d}^{-1}\right)$} \\
\cline { 2 - 3 } & $\mathbf{P}_{\mathbf{2}} \mathbf{O}_{\mathbf{5}}$ & $\mathbf{S}$ \\
\hline $\mathrm{T}_{1}\left(\mathrm{P}_{0} \mathrm{~S}_{0}\right)$ & 0 & 0 \\
\hline $\mathrm{T}_{2}\left(\mathrm{P}_{0} \mathrm{~S}_{1}\right)$ & 0 & 100 \\
\hline $\mathrm{T}_{3}\left(\mathrm{P}_{0} \mathrm{~S}_{2}\right)$ & 0 & 200 \\
\hline $\mathrm{T}_{4}\left(\mathrm{P}_{1} \mathrm{~S}_{0}\right)$ & 30 & 0 \\
\hline $\mathrm{T}_{5}\left(\mathrm{P}_{1} \mathrm{~S}_{1}\right)$ & 30 & 100 \\
\hline $\mathrm{T}_{6}\left(\mathrm{P}_{1} \mathrm{~S}_{2}\right)$ & 30 & 200 \\
\hline $\mathrm{T}_{7}\left(\mathrm{P}_{2} \mathrm{~S}_{0}\right)$ & 60 & 0 \\
\hline $\mathrm{T}_{8}\left(\mathrm{P}_{2} \mathrm{~S}_{1}\right)$ & 60 & 100 \\
\hline $\mathrm{T}_{9}\left(\mathrm{P}_{2} \mathrm{~S}_{2}\right)$ & 60 & 200 \\
\hline
\end{tabular}

Results and Discussion

1- Straw and Grain Yields of Wheat Plants

a) Straw yield

The main application effects of $\mathrm{P}$ or elemental $\mathrm{S}$ showed significant increases in the straw yield wheat plants (Table 3 and Fig. 1a). The phosphorus application at levels of 30 and $60 \mathrm{~kg} \mathrm{P}_{2} \mathrm{O}_{5} \mathrm{fed}^{-1}$ increased the main straw yield by 4.5 and $10.5 \%$, respectively, compared to the control. Moreover, the application of elemental sulphur at levels of 100 and 200 $\mathrm{kg} \mathrm{S}$ fed $^{-1}$ increased the main straw yield by 1.5 and $3.2 \%$, respectively, over the control.

The interaction application effect of $\mathrm{P}$ and $\mathrm{S}$ showed a significant steady increase in the straw yield of wheat. Table (4) shows that the application of sulphur at levels of 100 and $200 \mathrm{~kg} \mathrm{~S} \mathrm{fed}^{-1}$ caused increases in the straw yield of 0.8 and $1.6 \%$, respec- tively, while adding these two levels of sulphur with $30 \mathrm{~kg} \mathrm{P}_{2} \mathrm{O}_{5} \mathrm{fed}^{-1}$ increased these benefits of the straw yield to reach 4.81 and $6.62 \%$, respectively. Moreover, applying both respective sulphur levels with $60 \mathrm{~kg}$ $\mathrm{P}_{2} \mathrm{O}_{5}$ fed $^{-1}$ produced additional increases in the straw yield to attain 11.3 and $13.6 \%$ of the control. Therefore, the combined application of $\mathrm{P}$ and $S$ resulted in highly significant increases in the straw yield of wheat (Table 4 and Fig. 1b). The highest wheat straw yield of $2508.14 \mathrm{~kg} \mathrm{fed}^{-1}$ was obtained with using the $\mathrm{T}_{9}\left(\mathrm{P}_{2} \mathrm{~S}_{2}\right)$ treatment $\left(60 \mathrm{~kg} \mathrm{P}_{2} \mathrm{O}_{5}\right.$ and $200 \mathrm{~kg} \mathrm{~S}$ $\left.\mathrm{fed}^{-1}\right)$ while, the lowest one (2207.33 $\left.\mathrm{kg} \mathrm{fed}^{-1}\right)$ was recorded with $\mathrm{T}_{1}\left(\mathrm{P}_{0} \mathrm{~S}_{0}\right)$ treatment (control). Aulakh et al, (1990) and Singh et al, (1995) indicated that the nature of $\mathrm{P}$ and $\mathrm{S}$ interaction depended on their levels of application. 
Table 3. Main application effects of $P$ and $S$ on straw and grain yields as well as uptakes of $P$ and $\mathrm{Fe}, \mathrm{Zn}, \mathrm{Mn}$ and $\mathrm{Cu}$ by wheat plant

\begin{tabular}{|l|c|c|c|c|c|c|c|c|c|c|c|c|}
\hline \multirow{2}{*}{ Treatments } & \multicolumn{2}{|c|}{ Yield } & \multicolumn{9}{c|}{ Uptake } \\
\cline { 2 - 14 } & $\begin{array}{c}\text { Straw } \\
\text { (kg / fed) }\end{array}$ & $\begin{array}{c}\text { Grains } \\
\text { (kg /fed) }\end{array}$ & \multicolumn{2}{|c|}{ P kg/fed } & \multicolumn{2}{|c|}{ Fe g/fed } & \multicolumn{2}{c|}{ Zn g/fed } & \multicolumn{2}{c|}{ Mn g/fed } & \multicolumn{2}{c|}{ Cu g/fed } \\
\hline & & & Straw & Grain & Straw & Grain & Straw & Grain & Straw & Grain & Straw & Grain \\
\hline P0 & 2224.66 & 2483.00 & 3.19 & 8.74 & 152.74 & 93.18 & 36.48 & 81.49 & 45.88 & 77.85 & 20.03 & 20.38 \\
\hline P1 & 2313.56 & 2571.89 & 3.93 & 9.78 & 187.51 & 110.92 & 47.99 & 87.94 & 58.67 & 95.98 & 33.93 & 28.70 \\
\hline P2 & 2458.11 & 2720.33 & 4.92 & 11.26 & 218.91 & 91.66 & 54.32 & 103.41 & 62.57 & 91.04 & 34.00 & 35.67 \\
\hline LSD $_{0.01}$ & 5.08 & 5.44 & 0.05 & 0.07 & 1.01 & 0.93 & 0.78 & 3.37 & 0.79 & 0.57 & 0.52 & 0.54 \\
\hline S0 & 2296.67 & 2553.78 & 3.36 & 8.99 & 164.41 & 91.20 & 41.02 & 82.72 & 42.98 & 77.04 & 22.73 & 24.50 \\
\hline S1 & 2331.44 & 2592.11 & 4.14 & 10.09 & 195.59 & 99.66 & 47.52 & 93.99 & 58.29 & 90.62 & 29.27 & 28.85 \\
\hline S2 & 2368.17 & 2632.33 & 4.55 & 10.71 & 199.42 & 104.92 & 50.26 & 96.13 & 65.85 & 97.21 & 36.00 & 31.40 \\
\hline LSD $_{0.01}$ & 5.08 & 5.44 & 0.05 & 0.07 & 1.01 & 0.93 & 0.78 & 3.37 & 0.79 & 0.57 & 0.52 & 0.54 \\
\hline
\end{tabular}

The synergistic application effect of $\mathrm{P}$ and $\mathrm{S}$ may be due to utilization of high quantities of nutrients through the well developed root and shoot systems of the plants. These results confirm the earlier findings of Randhawa and Arora, (2000) on wheat and Choudhary and Dos (1996) on winter maize. In addition, Konde et al (1998) reported that the availability phosphorus in the soil causes favorable effects on plant growth.

Table 4. Interaction application effect of $P$ and $S$ on straw and grain yields of wheat plant

\begin{tabular}{|c|c|c|}
\hline Treatment & Straw yield $(\mathbf{k g} /$ fed) & Grain yield (kg / fed) \\
\hline $\mathrm{T}_{1}\left(\mathrm{P}_{0} \mathrm{~S}_{0}\right)$ & 2207.33 & 2467.33 \\
\hline $\mathrm{T}_{2}\left(\mathrm{P}_{0} \mathrm{~S}_{1}\right)$ & 2224.10 & 2480.67 \\
\hline $\mathrm{T}_{3}\left(\mathrm{P}_{0} \mathrm{~S}_{2}\right)$ & 2242.50 & 2501.22 \\
\hline $\mathrm{T}_{4}\left(\mathrm{P}_{1} \mathrm{~S}_{0}\right)$ & 2274.66 & 2530.59 \\
\hline $\mathrm{T}_{5}\left(\mathrm{P}_{1} \mathrm{~S}_{1}\right)$ & 2312.34 & 2572.31 \\
\hline $\mathrm{T}_{6}\left(\mathrm{P}_{1} \mathrm{~S}_{2}\right)$ & 2353.57 & 2621.65 \\
\hline $\mathrm{T}_{7}\left(\mathrm{P}_{2} \mathrm{~S}_{0}\right)$ & 2408.24 & 2663.32 \\
\hline $\mathrm{T}_{8}\left(\mathrm{P}_{2} \mathrm{~S}_{1}\right)$ & 2458.12 & 2723.29 \\
\hline $\mathrm{T}_{9}\left(\mathrm{P}_{2} \mathrm{~S}_{2}\right)$ & 2508.14 & 2774.32 \\
\hline $\mathrm{LSD}_{0.01}$ & 8.81 & 9.43 \\
\hline
\end{tabular}

\section{b) Grain yield}

Applying $\mathrm{P}$ at the level of 30 and $60 \mathrm{~kg} \mathrm{P}_{2} \mathrm{O}_{5}$ fed $^{-1}$ showed increases in the main wheat grain yield of 3.58 and $9.56 \%$, respectively, over the control (Table3 and Fig.1a). Also, element $\mathrm{S}$ application at levels of 100 and $200 \mathrm{~kg} \mathrm{~S}$ fed $^{-1}$ resulted in increases in the main wheat grain yield of 1.50 and $3.07 \%$, respectively, over the control (Fig. 1a)
The interaction of $\mathrm{P}$ and $\mathrm{S}$ levels increased their beneficial synergistic effect. The grain yield of wheat was increased by only 0.54 and $1.37 \%$ over the control when the element $\mathrm{S}$ was applied alone at levels of 100 and $200 \mathrm{~kg} \mathrm{~S} \mathrm{fed}^{-1}$, respectively. However, applying these respective $\mathrm{S}$ levels with $\mathrm{P}$ at a level of $30 \mathrm{~kg} \mathrm{P}_{2} \mathrm{O}_{5}$ fed $^{-1}$ produced increases in the grain yield of 4.25 and $6.25 \%$ over the control. Moreover, the addition of both re- 
spective $\mathrm{S}$ levels with $60 \mathrm{~kg} \mathrm{P}_{2} \mathrm{O}_{5}$ fed $^{-}$ ${ }^{1}$ gave increases in the grain yield of 10.37 and $12.44 \%$ (Table 4 and Fig. $1 \mathrm{~b})$. The highest grain yield of wheat of $2774.33 \mathrm{~kg} \mathrm{fed}^{-1}$ was obtained with applying $\mathrm{T}_{9}\left(\mathrm{P}_{2} \mathrm{~S}_{2}\right)$ treatment $(60 \mathrm{~kg}$
$\mathrm{P}_{2} \mathrm{O}_{5}$ and $200 \mathrm{~kg} \mathrm{~S} \mathrm{f}^{-1}$ ) but, the lowest one $\left(2467.33 \mathrm{~kg} \mathrm{fed}^{-1}\right)$ was recorded for the control treatment $\left(\mathrm{P}_{0} \mathrm{~S}_{0}\right)$. Similar results were reported by Kachhava et al (1997) and Chandra Deo and Khaldelwal
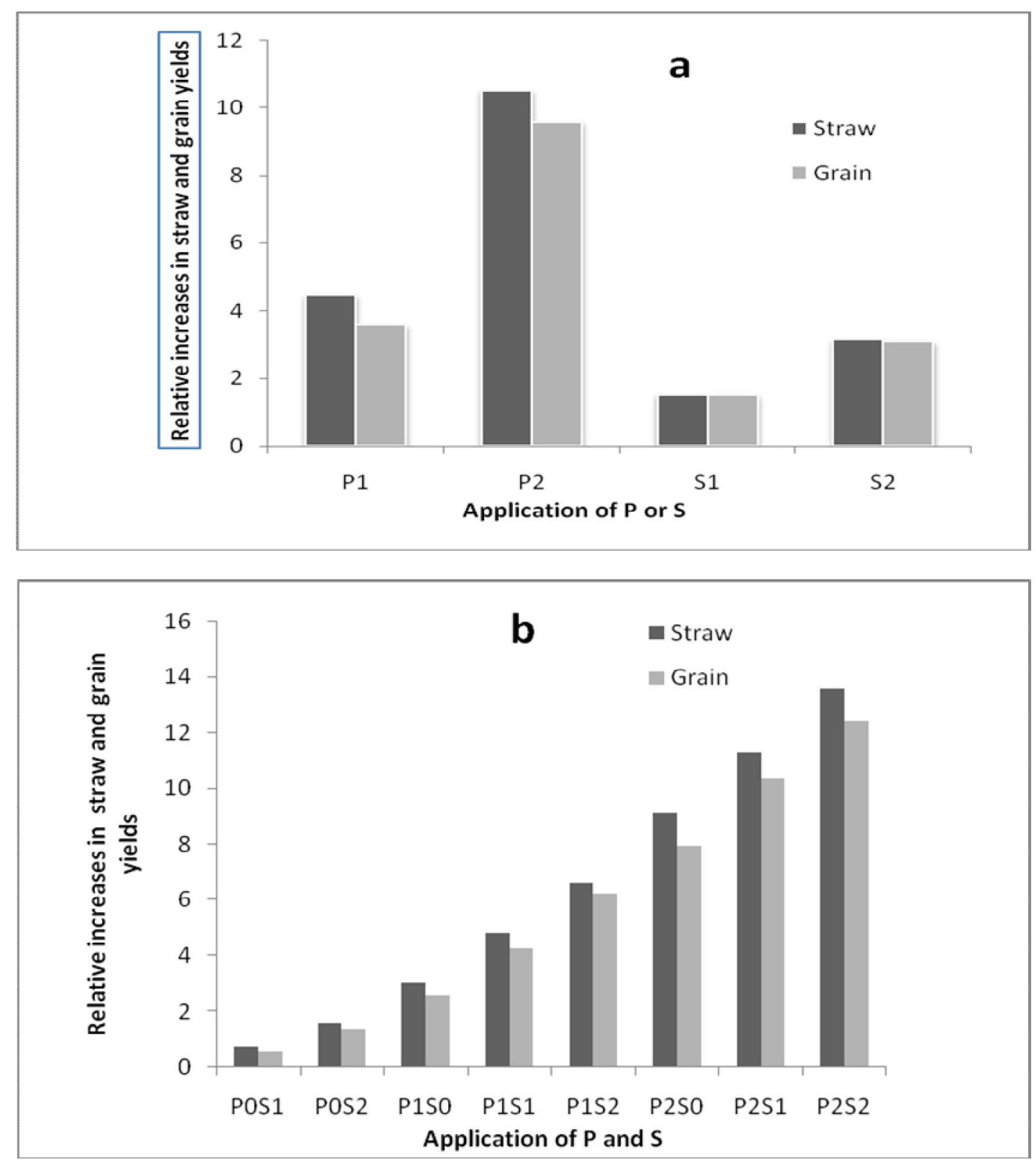

Figure 1: The relative increases in wheat straw and grain yields due to (a) main and (b) interaction application effect of $\mathrm{P}$ and $\mathrm{S}$.

The increase in the grain yield may be attributed to the better root development with increasing the levels of these nutrients. Phosphorus 
that is constituent of nucleic acid and different types of proteins, might stimulate cell division and increase the plant growth. Choudhary and Das, (1996) also reported a beneficial effect of applying sulphur due to lowering the soil $\mathrm{pH}$ and improving the chemical conditions of the soil.

\section{2- Phosphorus Uptake by Wheat} Plants.

The applied levels of phosphorus ( 30 and $60 \mathrm{~kg} \mathrm{P}_{2} \mathrm{O}_{5}$ fed $^{-1}$ ) to the soil significantly increased the main $\mathrm{P}$ uptake by wheat straw and grains (Table 3 and Fig.2). Similarly, the main $P$ uptake was significantly increased with applying both levels of sulphur (100 and $200 \mathrm{~S} \mathrm{~kg} \mathrm{fed}^{-1}$ ). The $\mathrm{P}$ uptake by wheat straw was increased by 23.19 and $54.23 \%$, and the $\mathrm{P}$ uptake by grains was raised by 11.89 and $28.83 \%$ over the control when $\mathrm{P}$ was applied alone to the soil at levels of 30 and $60 \mathrm{~kg} \mathrm{P}_{2} \mathrm{O}_{5} \mathrm{fed}^{-1}$, respectively. Also, elemental S applied alone at levels of 100 and 200 $\mathrm{kg} \mathrm{S}$ fed $^{-1}$ resulted in increases in the straw P uptake of 23.19 and $35.42 \%$, respectively, and in the grain $\mathrm{P}$ uptake of 12.23 and $19.13 \%$, respectively, over the control.

The interaction of both factors, $\mathrm{P}$ and $\mathrm{S}$ produced significant steady increases in P uptakes by both straw and grains (Tables 5 and 6). The $\mathrm{P}$ uptake by wheat plants ranged from 2.98 to $5.60 \mathrm{~kg} \mathrm{fed}^{-1}$ by straw and from 8.32 to $12.25 \mathrm{~kg} \mathrm{fed}^{-1}$ by grains. Highest $\mathrm{P}$ uptakes by straw and grains of 5.60 and $12.25 \mathrm{~kg} \mathrm{fed}^{-1}$, respectively, were recorded using $\mathrm{T}_{9}$ treatment $\left(60 \mathrm{~kg} \mathrm{P}_{2} \mathrm{O}_{5}\right.$ and $200 \mathrm{~kg} \mathrm{~S}$ $\left.\mathrm{fed}^{-1}\right)$. Similar results were indicated by Teotia et al (2000) and Islam et al (2006) in mungbean.

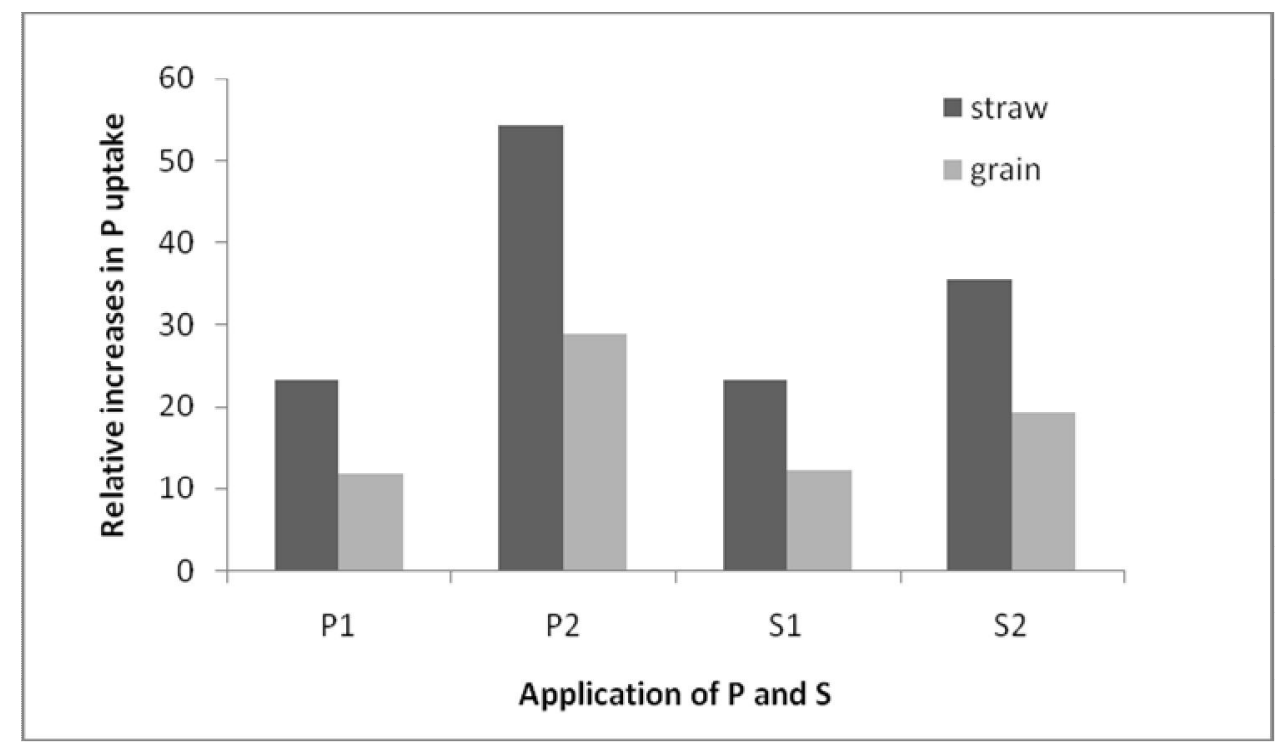

Figure 2: The relative increases in $\mathrm{P}$ uptake by wheat straw and grains induced by the application of $\mathrm{P}$ and $\mathrm{S}$ 
Table 5. The application effect of $P$ and $S$ on $P, F e, ~ Z n, M n$ and $\mathrm{Cu}$ uptakes by straw of wheat plants.

\begin{tabular}{|c|c|c|c|c|c|}
\hline \multirow{2}{*}{ Treatments } & \multicolumn{5}{|c|}{ Uptake by straw } \\
\cline { 2 - 6 } & $\mathbf{P}(\mathbf{k g} / \mathbf{f e d})$ & $\mathbf{F e}(\mathbf{g} / \mathbf{f e d})$ & $\mathbf{Z n}(\mathbf{g} / \mathbf{f e d})$ & $\mathbf{M n} \mathbf{( g / f e d )}$ & $\mathbf{C u} \mathbf{( g / f e d )}$ \\
\hline $\mathrm{T}_{1}\left(\mathrm{P}_{0} \mathrm{~S}_{0}\right)$ & 2.98 & 138.33 & 32.23 & 37.38 & 18.10 \\
\hline $\mathrm{T}_{2}\left(\mathrm{P}_{0} \mathrm{~S}_{1}\right)$ & 3.21 & 167.99 & 36.62 & 46.56 & 18.68 \\
\hline $\mathrm{T}_{3}\left(\mathrm{P}_{0} \mathrm{~S}_{2}\right)$ & 3.84 & 151.89 & 40.59 & 53.70 & 23.32 \\
\hline $\mathrm{T}_{4}\left(\mathrm{P}_{1} \mathrm{~S}_{0}\right)$ & 3.17 & 164.99 & 43.07 & 44.13 & 24.57 \\
\hline $\mathrm{T}_{5}\left(\mathrm{P}_{1} \mathrm{~S}_{1}\right)$ & 3.99 & 184.37 & 48.41 & 57.19 & 31.45 \\
\hline $\mathrm{T}_{6}\left(\mathrm{P}_{1} \mathrm{~S}_{2}\right)$ & 4.66 & 213.17 & 52.49 & 74.69 & 45.89 \\
\hline $\mathrm{T}_{7}\left(\mathrm{P}_{2} \mathrm{~S}_{0}\right)$ & 3.94 & 189.11 & 47.76 & 47.44 & 25.52 \\
\hline $\mathrm{T}_{8}\left(\mathrm{P}_{2} \mathrm{~S}_{1}\right)$ & 5.22 & 234.41 & 57.52 & 71.12 & 37.69 \\
\hline $\mathrm{T}_{9}\left(\mathrm{P}_{2} \mathrm{~S}_{2}\right)$ & 5.60 & 233.19 & 57.69 & 69.15 & 38.79 \\
\hline $\mathrm{LSD}_{0.01}$ & 0.0 .01 & 1.91 & 1.35 & 1.36 & 0.90 \\
\hline
\end{tabular}

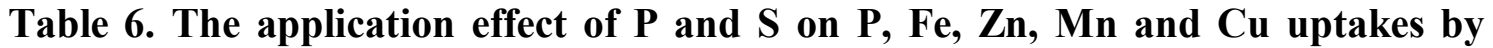
grain of wheat plants.

\begin{tabular}{|c|c|c|c|c|c|}
\hline \multirow{2}{*}{ Treatments } & \multicolumn{5}{|c|}{ Uptake by grain } \\
\cline { 2 - 6 } & $\mathbf{P}(\mathbf{k g} / \mathbf{f e d})$ & $\mathbf{F e}(\mathbf{g} / \mathbf{f e d})$ & $\mathbf{Z n}(\mathbf{g} / \mathbf{f e d})$ & $\mathbf{M n} \mathbf{( g / f e d})$ & $\mathbf{C u} \mathbf{( g / f e d )}$ \\
\hline $\mathrm{T}_{1}\left(\mathrm{P}_{0} \mathrm{~S}_{0}\right)$ & 8.32 & 87.51 & 75.50 & 72.70 & 17.77 \\
\hline $\mathrm{T}_{2}\left(\mathrm{P}_{0} \mathrm{~S}_{1}\right)$ & 8.82 & 90.17 & 83.02 & 75.66 & 19.10 \\
\hline $\mathrm{T}_{3}\left(\mathrm{P}_{0} \mathrm{~S}_{2}\right)$ & 9.09 & 101.37 & 85.95 & 85.20 & 24.26 \\
\hline $\mathrm{T}_{4}\left(\mathrm{P}_{1} \mathrm{~S}_{0}\right)$ & 8.69 & 99.63 & 79.97 & 85.28 & 24.04 \\
\hline $\mathrm{T}_{5}\left(\mathrm{P}_{1} \mathrm{~S}_{1}\right)$ & 9.88 & 117.04 & 88.40 & 99.81 & 29.58 \\
\hline $\mathrm{T}_{6}\left(\mathrm{P}_{1} \mathrm{~S}_{2}\right)$ & 10.78 & 116.09 & 95.45 & 102.85 & 32.49 \\
\hline $\mathrm{T}_{7}\left(\mathrm{P}_{2} \mathrm{~S}_{0}\right)$ & 9.99 & 86.47 & 92.68 & 73.15 & 31.70 \\
\hline $\mathrm{T}_{8}\left(\mathrm{P}_{2} \mathrm{~S}_{1}\right)$ & 11.56 & 91.23 & 110.57 & 96.40 & 37.85 \\
\hline $\mathrm{T}_{9}\left(\mathrm{P}_{2} \mathrm{~S}_{2}\right)$ & 12.25 & 97.28 & 106.99 & 103.58 & 37.45 \\
\hline $\mathrm{LSD}_{0.01}$ & 0.13 & 1.61 & 5.84 & 0.99 & 0.93 \\
\hline
\end{tabular}

\section{3-Micronutrient Uptakes by Wheat} Plants.

a) Iron (Fe) uptake

The application of $\mathrm{P}$ at levels of 30 and $60 \mathrm{~kg} \mathrm{P}_{2} \mathrm{O}_{5}$ fed $^{-1}$ increased the main Fe uptake by straw to reach 22.7 and $43.32 \%$, respectively, while, adding $\mathrm{S}$ at levels of 100 and $200 \mathrm{~kg}$ $\mathrm{S}$ fed ${ }^{-1}$ raised the straw main $\mathrm{Fe}$ uptake to attain 18.96 and $21.29 \%$, respectively, over the control (Table 3 and Fig. 3a). Also, elemental S additions at levels 100 and $200 \mathrm{~kg} \mathrm{~S} \mathrm{fed}^{-1}$ gave increases in the main Fe uptake by wheat grains of 9.28 and $15.04 \%$, respectively, over the control. However, addition of $\mathrm{P}$ at levels 30 and 60 $\mathrm{kg} \mathrm{P}_{2} \mathrm{O}_{5}$ fed $^{-1}$ produced a $19.04 \%$ increase and a $1.63 \%$ decreases, respectively, in the main $\mathrm{Fe}$ uptake by grains compared to the control. 


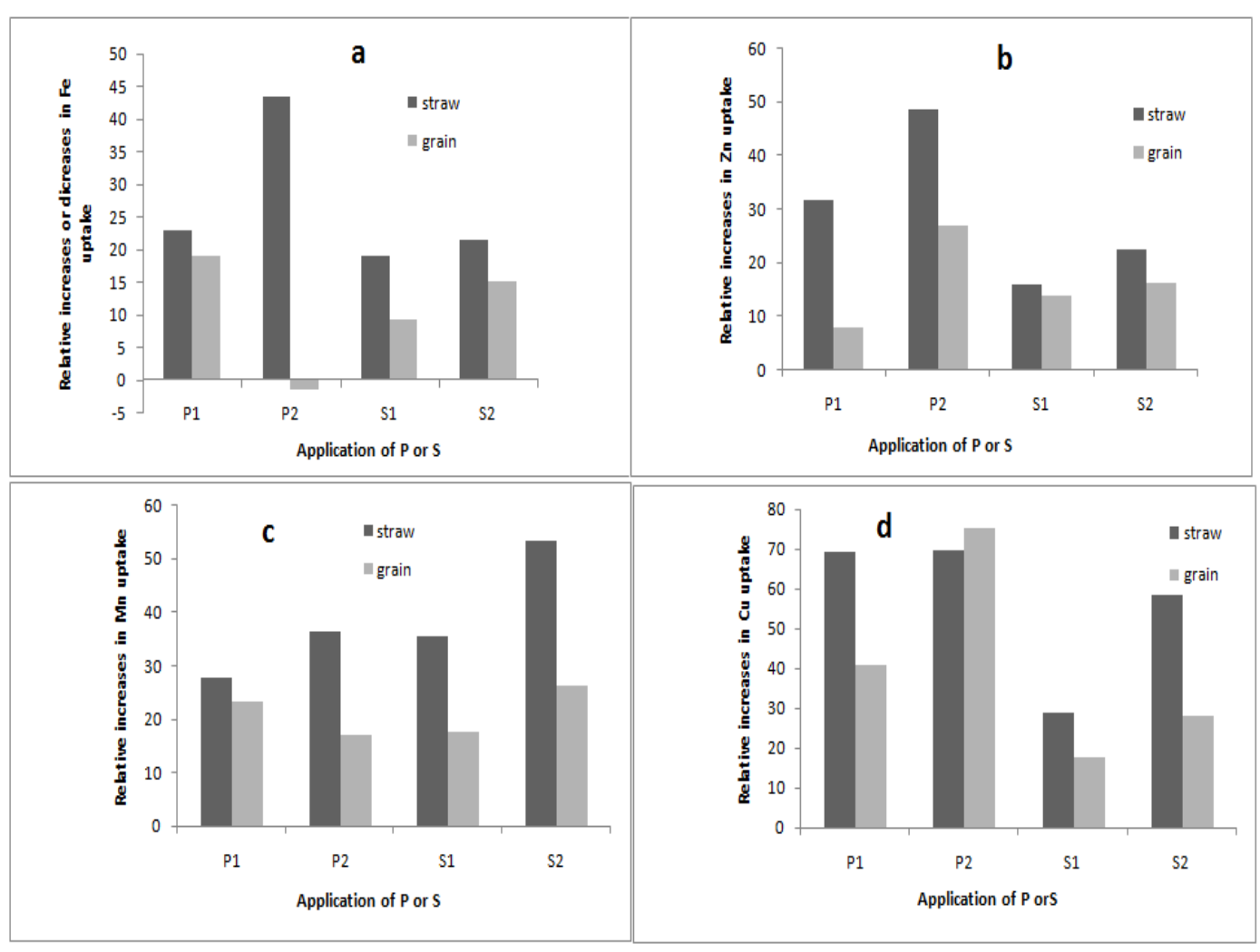

Figure 3: The relative increases or decreases of (a) Fe, (b) $\mathrm{Zn}$, (c) $\mathrm{Mn}$ and (d) $\mathrm{Cu}$ uptakes by straw and grains induced by the application of $\mathrm{P}$ or $\mathrm{S}$

The interaction of $\mathrm{P}$ and $\mathrm{S}$ levels showed a significant effect on Fe uptake by both straw and grains (Tables 5 and 6). The Fe uptake by wheat straw was increased by only 29.66 and $13.56 \mathrm{~g} \mathrm{fed}^{-1}$ over the control by the application of 100 and $200 \mathrm{~kg} \mathrm{~S}$ $\mathrm{fed}^{-1}$, respectively, without adding $\mathrm{P}$. However, using $30 \mathrm{~kg} \mathrm{P}_{2} \mathrm{O}_{5} \mathrm{fed}^{-1}$ with these respective applied $\mathrm{S}$ levels produced Fe uptake by straw of 46.04 and $74.84 \mathrm{~g} \mathrm{fed}^{-1}$, respectively, over the control,. Moreover, adding $60 \mathrm{~kg}$ $\mathrm{P}_{2} \mathrm{O}_{5}$ fed $^{-1}$ in a combination with both $\mathrm{S}$ levels resulted in 69.08 and $94.84 \mathrm{~g}$ $\mathrm{fed}^{-1}$, respectively, of $\mathrm{Fe}$ uptake by straw over the control (Table 5). Also, the addition of both respective levels $\mathrm{S}$ without applying $\mathrm{P}$ increased the Fe uptake by grains by 2.66 and $13.86 \mathrm{~g} \mathrm{fed}^{-1}$ over the control. However, applying $30 \mathrm{~kg} \mathrm{P}_{2} \mathrm{O}_{5}$ fed $^{-1}$ with100 and $200 \mathrm{~kg} \mathrm{~S}^{-1} \mathrm{fed}^{-1}$ gave Fe uptake by grains of 29.53 and $28.58 \mathrm{~g} \mathrm{fed}^{-1}$, respectively. A respective Fe uptake by grains was recorded with adding 60 $\mathrm{kg} \mathrm{P}_{2} \mathrm{O}_{5}$ fed $^{-1}$ combined with both $\mathrm{S}$ levels of 3.72 and $9.77 \mathrm{~g} \mathrm{fed}^{-1}$.

The addiction of $\mathrm{T}_{6} \quad\left(\mathrm{P}_{1} \mathrm{~S}_{2}\right)$ treatment $\left(30 \mathrm{~kg} \mathrm{P}_{2} \mathrm{O}_{5}\right.$ and $200 \mathrm{~kg} \mathrm{~S}$ $\mathrm{fed}^{-1}$ ) showed the highest Fe uptake by wheat straw $\left(213.17 \mathrm{~g} \mathrm{fed}^{-1}\right)$. The lowest Fe uptake by straw (138.33 g fed $\left.^{-1}\right)$ was recorded for the $\mathrm{T}_{1}\left(\mathrm{P}_{0} \mathrm{~S}_{0}\right)$ treatment. Moreover, the highest value $\left(117.04 \mathrm{~g} \mathrm{fed}^{-1}\right)$ of Fe uptake by wheat grains was found for the $T_{5}$ $\left(\mathrm{P}_{1} \mathrm{~S}_{1}\right)$ treatment, and the lowest one $\left(86.47 \mathrm{~g} \mathrm{fed}^{-1}\right)$ was obtained for the $\mathrm{T}_{7}\left(\mathrm{P}_{2} \mathrm{~S}_{0}\right)$ treatment (Table 6).

So, sulphur application resulted in increases in Fe uptake by wheat plants as it was also indicated by Malewar and Ismail (1997). They indi- 
cated that the application of $80 \mathrm{mg} \mathrm{S}$ $\mathrm{kg}^{-1}$ increased the available $\mathrm{Fe}$ by $49 \%$. A close relationship exists between $\mathrm{Fe}$ and $\mathrm{S}$ metabolism in plants.

\section{b) Zinc (Zn) uptake}

The application of $\mathrm{P}$ or $\mathrm{S}$ had significant increases in the main $\mathrm{Zn}$ uptake by wheat straw and grains (Table 3). The application of $\mathrm{P}$ at levels of 30 and $60 \mathrm{~kg} \mathrm{P}_{2} \mathrm{O}_{5}$ fed $^{-1}$ resulted in an increase in the main $\mathrm{Zn}$ uptake by straw of 31.6 and 48.9 $\% \%$, respectively. Also, S application at levels of 100 and $200 \mathrm{~kg} \mathrm{fed}^{-1}$ showed an increase in the main $\mathrm{Zn}$ uptake by straw of 15.8 and $22.5 \%$, respectively. Moreover, the respective increases in the main $\mathrm{Zn}$ uptake by grains were 7.9 and $26.8 \%$ due to the applied P levels as well as 13.6 and $16.2 \%$ due to the applied S levels (Table 3 and Fig. 3b).

The results in Tables 5 and 6 showed that the interaction of $\mathrm{P}$ and $\mathrm{S}$ levels had significant increases in the $\mathrm{Zn}$ uptake by straw and grains. Additions of sulphur at 100 and $200 \mathrm{~kg} \mathrm{~S}$ $\mathrm{fed}^{-1}$ without applying $\mathrm{P}$ showed an increase in the $\mathrm{Zn}$ uptake by straw of 4.36 and $8.75 \mathrm{~g} \mathrm{fed}^{-1}$, respectively, over the control. However, the combination of $30 \mathrm{~kg} \mathrm{P}_{2} \mathrm{O}_{5} \mathrm{fed}^{-1}$ with these levels of $\mathrm{S}$ had an increase in the straw $\mathrm{Zn}$ uptake of 16.18 and $20.26 \mathrm{~g} \mathrm{fed}^{-1}$, respectively, over the control. Moreover, adding $60 \mathrm{~kg} \mathrm{P}_{2} \mathrm{O}_{5}$ $\mathrm{fed}^{-1}$ with these $\mathrm{S}$ levels caused an increase in the straw $\mathrm{Zn}$ uptake of 25.26 and $25.46 \mathrm{~g} \mathrm{fed}^{-1}$ over the control, respectively. The highest value of $\mathrm{Zn}$ uptake by straw $\left(57.69 \mathrm{~g} \mathrm{fed}^{-1}\right)$ was observed for the plot receiving the $\mathrm{T}_{9}$ treatment $\left(60 \mathrm{~kg} \mathrm{P}_{2} \mathrm{O}_{5}\right.$ and 200 $\left.\mathrm{kg} \mathrm{S} \mathrm{fed}^{-1}\right)$. However, the lowest value of $\mathrm{Zn}$ uptake by straw (32.23 g fed $^{-1}$ ) was recorded for the $T_{1}$ treatment (Table 5). The $\mathrm{Zn}$ uptake by wheat grains had increases by 7.52 and $10.45 \mathrm{~g} \mathrm{fed}^{-1}$ with adding sulphur alone at levels of 100 and $200 \mathrm{~kg} \mathrm{~S}$ $\mathrm{fed}^{-1}$, respectively. However, adding $30 \mathrm{~kg} \mathrm{P}_{2} \mathrm{O}_{5}$ fed $^{-1}$ with these sulphur levels produced respective increases in the grain $\mathrm{Zn}$ uptake of 12.90 and $19.95 \mathrm{~g} \mathrm{fed}^{-1}$ over the control Moreover, applying $60 \mathrm{~kg} \mathrm{P}_{2} \mathrm{O}_{5} \mathrm{fed}^{-1}$ with both sulphur levels produced respective increases of 17.18 and $35.07 \mathrm{~g}$ $\mathrm{fed}^{-1}$ in the grain $\mathrm{Zn}$ uptake over the control. The $\mathrm{Zn}$ uptake by grains had the highest value of $110.57 \mathrm{~g} \mathrm{fed}^{-1}$ with using the $T_{8}$ treatment and the lowest one of $75.50 \mathrm{~g} \mathrm{fed}^{-1}$ with the $\mathrm{T}_{1}$ treatment (Table 6).

Due to the acidifying effect of $\mathrm{S}$ oxidation, the availability of nutrients like $\mathrm{P}, \mathrm{Zn}, \mathrm{Cu}, \mathrm{Fe}$ and $\mathrm{Mn}$ is influenced (Hilal et al, 1990b). The application of $\mathrm{P}$ and $\mathrm{S}$ resulted in increases in the uptakes of these nutrients by plants, which may be due to the availability increase of these nutrients in the soil. The high application level of $\mathrm{P}\left(60 \mathrm{P}_{2} \mathrm{O}_{5} \mathrm{fed}^{-1}\right)$ however, resulted in a decrease in the $\mathrm{Zn}$ uptake by wheat grains. This may be either due to the dilution effect when the plant growth rate exceeded that of the $\mathrm{Zn}$ uptake or due to the reduction in the translocation of $\mathrm{Zn}$ from roots to leaves (Tandon, 2001) .The hypothesis that $\mathrm{P}$ application resulted in the formation of insoluble zinc phosphate is not true and many workers have shown that $\mathrm{P}$ application has no effect on the available $\mathrm{Zn}$ contents of the soil (Tandon, 2001). The induced $\mathrm{Zn}$ uptake increase by $\mathrm{S}$ application has been reported by Sharma et al, (1990) and Babhulkar et al, (2000). The in- 
crease in $\mathrm{Zn}$ uptake may be due to the increase in the root surface area resulting from better growth due to $\mathrm{S}$ supply as both sulphur and zinc are known to increase root growth. Babhulkar et al, (2000) indicated that $\mathrm{Zn}$ and $\mathrm{S}$ interaction occurred at both $\mathrm{ab}$ sorption sites and within plants.

c) Manganese (Mn) uptake

Phosphorus applications at levels of 30 and $60 \mathrm{~kg} \mathrm{P}_{2} \mathrm{O}_{5}$ fed $^{-1}$ raised the main straw Mn uptake by 27.9 and $36.3 \%$, respectively, compared to the control (Table 3 and Fig. 3c). Also, sulphur application at levels of 100 and $200 \mathrm{~kg} \mathrm{~S}^{-1}$ red ${ }^{-1}$ resulted in increases in the main straw Mn uptake of 35.6 and $53.1 \%$, respectively, compared to the control. In addition, both $\mathrm{P}$ applied levels showed the respective increases in the main Mn uptake by grains of 23.28 and $16.92 \%$. Also, both $\mathrm{S}$ added levels produced respective increases in the main $\mathrm{Mn}$ uptake by grains by 17.62 and 26.18 compared to the control.

There was a significant interaction effect of $\mathrm{P}$ and $\mathrm{S}$ applications on the Mn uptake by wheat straw and grains (Tables 5 and 6). The highest amount of $\mathrm{Mn}$ taken up by wheat straw $\left(71.12 \mathrm{~g} \mathrm{fed}^{-1}\right)$ was recorded for the $\mathrm{T}_{8}$ treatment, while, the lowest one $\left(37.38 \mathrm{~g} \mathrm{fed}^{-1}\right)$ was for the $T_{1}$ treatment. The Mn uptake by straw was increased by 9.18 and $16.32 \mathrm{~g}$ fed $^{-1}$ over the control with applying 100 and $200 \mathrm{~kg} \mathrm{~S} \mathrm{fed}^{-1}$ respectively without adding $\mathrm{P}$. However, $\mathrm{P}$ additions of $30 \mathrm{~kg} \mathrm{P}_{2} \mathrm{O}_{5}$ fed $^{-1}$ combined with both $\mathrm{S}$ levels produced increases in the straw Mn uptake of 19.81 and $37.31 \mathrm{~g} \mathrm{fed}^{-1}$, respectively, over the control. However, $\mathrm{P}$ additions at 60 $\mathrm{kg} \mathrm{P}_{2} \mathrm{O}_{5}$ fed $^{-1}$ with applying $\mathrm{S}$ at both levels gave increases in the straw $\mathrm{Mn}$ uptake of 33.74 and $31.77 \mathrm{~g} \mathrm{fed}^{-1}$, respectively, over the control.

The application of $\mathrm{S}_{1}$ and $\mathrm{S}_{2}$ alone increased the $\mathrm{Mn}$ uptake by wheat grains by 2.96 and $12.50 \mathrm{fed}^{-1}$, respectively, over the control (Table $6)$. Moreover, the combination of 30 $\mathrm{kg} \mathrm{P}_{2} \mathrm{O}_{5}$ fed $^{-1}$ with both applied S levels increased the grain Mu uptake by 24.11 and $30.15 \mathrm{~g} \mathrm{fed}^{-1}$, respectively, over the control. Also, mixing $60 \mathrm{~kg}$ $\mathrm{P}_{2} \mathrm{O}_{5}$ fed $^{-1}$ with $\mathrm{S}$ applied levels increased the grain Mn uptake by 23.70 and $30.88 \mathrm{~g} \mathrm{fed}^{-1}$. The highest amount of $\mathrm{Mn}$ taken up by wheat grains $\left(103.58 \mathrm{~g} \mathrm{fed}^{-1}\right)$ was recorded for the $\mathrm{T}_{9}$ treatment $\left(60 \mathrm{~kg} \mathrm{P}_{2} \mathrm{O}_{5}\right.$ and $200 \mathrm{~kg}$ $\mathrm{S}$ fed $\left.^{-1}\right)$ while, the lowest one $(72.70$ $\mathrm{g} \mathrm{fed}^{-1}$ ) was signed to the $\mathrm{T}_{1}$ treatment.

So, the application of $\mathrm{P}$ had a significant effect on the Mn uptake by wheat plants. The possible mechanism that is responsible for the less uptake of Mn at high nutrient application levels may be that other cations also compete with $\mathrm{Mn}$ for the transport across membranes. Applications of $\mathrm{S}$ had a significant effect on the Mn uptake by wheat plants. The interaction of $\mathrm{S}$ and $\mathrm{Mn}$ is least studied. The mechanism that is responsible for the increased $\mathrm{Mn}$ uptake is not known. Applications of acid $\left(\mathrm{NH}_{4}{ }^{+}\right)$forming fertilizer may increase the availability of Mn (Havlin et al, 2007).

\section{d) Copper (Cu) uptake.}

There was a significant effect on the main $\mathrm{Cu}$ uptake by wheat straw and grains due to the applied levels of $\mathrm{P}$ or $\mathrm{S}$. The application of $\mathrm{P}\left(\mathrm{P}_{1}\right.$ and $\mathrm{P}_{2}$ ) resulted in increases in the main $\mathrm{Cu}$ uptake by wheat straw of 69.3 and 
$69.7 \%$, respectively, over the control. Also, $\mathrm{S}\left(\mathrm{S}_{1}\right.$ and $\left.\mathrm{S}_{2}\right)$ levels showed increases in this main respect of 28.8 and $58.4 \%$, respectively, over the control. Furthermore, the application of $\mathrm{P}$ levels $\left(\mathrm{P}_{1}\right.$ and $\left.\mathrm{P}_{2}\right)$ resulted in increases in the main $\mathrm{Cu}$ uptake by grains of 40.82 and $75.02 \% \%$, respectively, over the control, but $\mathrm{S}_{1}$ and $\mathrm{S}_{2}$ application raised the main $\mathrm{Cu}$ uptake by grains of 17.75 and 28.16 $\%$, respectively, over the control (Table 3 and Fig.3d).

Both applied levels of $\mathrm{P}$ and $\mathrm{S}$ had significant effects on the $\mathrm{Cu}$ uptake by wheat straw and grains (Table 5 and 6). The maximum value of $\mathrm{Cu}$ uptake (45.89 $\mathrm{g} \mathrm{fed}^{-1}$ ) by straw was recorded for the $\mathrm{T}_{6}$ treatment $(30 \mathrm{~kg}$ $\mathrm{P}_{2} \mathrm{O}_{5}$ and $200 \mathrm{~kg} \mathrm{~S} \mathrm{fed}^{-1}$ ) and the minimum one $\left(18.10 \mathrm{~g} \mathrm{fed}^{-1}\right)$ was for the $\mathrm{T}_{1}$ treatment (Table 5). Also, the highest amount of $\mathrm{Cu}$ taken up (37.85 $\mathrm{g} \mathrm{fed}^{-1}$ ) by grains was obtained with the $\mathrm{T}_{8}$ treatment $\left(60 \mathrm{~kg} \mathrm{P}_{2} \mathrm{O}_{5}\right.$ and 100 $\mathrm{kg} \mathrm{S} \mathrm{fed}{ }^{-1}$ ) while, the lowest one (17.77 $\mathrm{g} \mathrm{fed}^{-1}$ ) was with $\mathrm{T}_{1}$ treatment (Table 6). The induced increase in $\mathrm{Cu}$ uptake by wheat plants due to phosphorus applications may be attributed to the increased root growth.

\section{Conclusion}

The interaction of phosphorus and sulphur application depends on the soil fertility status, levels of applied nutrients, test crop and climatic conditions. The effect of phosphorus and sulphur application was synergistic at all $\mathrm{P}$ and $\mathrm{S}$ levels. The combination of $60 \mathrm{Kg}$ P2O5 fed $\mathrm{fon}^{-1}$ and $200 \mathrm{~kg}$ $\mathrm{S}$ fed $^{-1}$ resulted in the highest values of wheat straw and grain yield as well as the highest uptake values of $\mathrm{P}, \mathrm{Fe}$, $\mathrm{Zn}$ and $\mathrm{Cu}$. This will increase the fertilizer use efficiency and save pre- cious and cost inputs. Also, these will minimize the threats of soil and water pollution.

\section{References}

Abdin, M, Z., A. Ahmed, I. Khan, A. Jamal and M. Iqbal. 2003 Sulphur interaction with other nutrients. In. Abrol, Y. P. and A. Ahmed (eds), Sulphur in Plants, p: 359. Kluwer Academic Publication, The Netherlands.

Alam, S. M., S. Azam, S. Ali and M. Iqbal, 2003. Wheat yield and $P$ fertilizer as influenced by rate and integrated use of chemical and organic fertilizer. Pak. J. Soil Sci. 22(2): 72-76.

Aulakh, M. S., N. S. Pasricha and A. S. Azad, 1990 Phosphorus-Sulphur interrelationship for soybean on $\mathrm{P}$ and S deficient soil. Soil Sci., 150: 705-709.

Babhulkar, M. S., D. Kar, W. P. Bodole and S. S. Balpande. 2000. Effect of sulphur and $\mathrm{Zn}$ on yield, quality and butrient uptake by safflower in Vertisol. J. Ind. Soc. Soil Sci., 48: 541-543.

Bakhshipour, R., E. Kahneh and P. A. Oskoei, 2008. Interaction studies of $\mathrm{P}$ and $\mathrm{Zn}$ in tea seedlings inoculated with Arbucular mycorrhizal fungi. Asian J. Chem., 20: 11751178.

Chandra Deo and R. B. Khaldelwal, 2009. Effect of P and S nutrient on yield and quality of chickpea (cicer arietinum L.). J. Indain. Soc. Soil Sci., 57: 352-356.

Choudhary, H. P. and S. K. Das, 1996. Effect of $\mathrm{P}, \mathrm{S}$ and Mo application on yield of rainfed blackgram and their residual effect on safflower, soil and soil and water conservation in eroded soil. J. Indain Soc. Soil Sci., 44:741-745.

Gomez, K. A. and A. A. Gomez, 1984. Statistical Procedures for Agricul- 
ture Reseach. Johan Wiley and Sone. New York, U. S. A.

Havlin, J. L., J. D. Beation, S. L. Tisdale and W. L. Nelson. 2007. Soil Fertility and Fertilizer, An Introduction to Nutrient Management, $7^{\text {th }}$ edition p: 221. Pearson Education Inc. Singapore.

Hedge, D. M. and I. Y. L. N. Murthy. 2005. Management of secondary nutrients. Indian J. Fert., 9: 90-100.

Hilal, M.H., H. El-Lakkany and H. ElSheemy. 1990b. Effect of sulphur and long term fertilizer application program on rhizosphere and yield of peanut in sandy soils. In. Proc. Middle East Sulphur Symposium. P: 217. 12.16 February, 1990, Cairo.

Islam, M. N., S. Hoque and A. Islam, 2006. Effect of PxS interactions on nutrient concentration and yield of wheat, rice and mungbean. J. Indain. Soc. Soil Sce., 54: 86-91.

Kachhava, K. G., D. S. Gawande, O. D. Kohire and S. S. Mane, 1997. Influence of various sources and levels of sulphur on nodulation, yield and uptake of nutrient by chickpea. J. Indian Soc. Soil Sci., 45:590-591.

Konde, B. K., P. M. Managava and R. B. Sonawane, 1998. Effect of rhizobium loti, vesicular arbuscular mycorrhizae and P levels on nodulation, yield and nutrient uptake by chickpea (Cicer arietinum L.). J. Indian Soc. Soil Sci., 46: 465-467.

Malewar, G. U. and S. Ismail. 1997. Sulphur in balanced fertilization in wesrem India. Proc. The TS/FSI/IFA Sypsosium on Sulphur in Balaced Fertilization. P: 14. New Delhi, India.

Parkinson, J. A., and S. E. Allen, 1975. A wet oxidation procedure suitable for the determination of nitrogen and mineral nutrients in biological material. Comm. Soil Sci. Plant Anal. 6:1-11.

Randhawa, P. S and C. L. Arora. 2000. Phodhporus-sulphur interaction effects on dry matter yield and nutrient uptake by wheat. J. Indian Soc. Soil Sce., 48: 536-544.

Sharma, U. C., 1990. Effect of Zn and S on nutrient uptake and yield of mustard. J. In. Soc. Soil Sci., 38: 696-701.

Shuaib, K., M. Ansar, M. A. Ali, A.Sher, G. Ahmed and M. Rashid, 2003. Effect of phosphorus on the yield and components of wheat variety (Inqlab-91) under rainfed conditions. Sarhad J. Agric. Vol. 25: 2124.

Singh, V., V. Kumar and S. P. S. Karawasra, 1995. Interaction of sulphurand zinc on dry matter yield, concentration and uptake of sulphur in green gram (Vigan radiate L.). Crop Res., 9: 32-41.

Tandon, H. L. S., 2001. Management of nutrient interactions in agriculture, p: 142. Fertilizer Development and Consultation Organization, New Dlhi, India.

Teotia, U. S., V. S. Mehta and P. C. Srivastava, 2000. Phosphours-Sulphur interaction in moongbean (Vigan radiate L. Wilczek): I. Yield, phosphours and sulphur contents. Legume Res., 23: 106-109.

Tiwari, K. N. and B. R. Gupta. 2006. Sulphur for sustainable high yield agriculture in Uttar Pradesh. Indian J. Fert., 1: 37-52.

Tufemkci, S., F. Somnez and R. I. G. Sensoy. 2005. Effect of Arbuscular mycorrhiza fungus inoculation and phosphorus and nitrogen fertilization on some plant growth parameters and nutrient contents of chickpea. J. Biol. Sci., 5: 738-743. 
تاثير اضافة الفوسفور والكبريت على المحصول وامتصاص الفوسفور والعناصر الصغرى بواسطة نباتات القمح وامتصاص

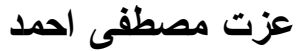

قسم الار اضى و المياه - كلية الزر اعة - جامعة أسيوط

أجريت تجربة حقلية فى المزرعة البحثية بقسم الار اضى و المياه - كلية الزر اعة - جامعة

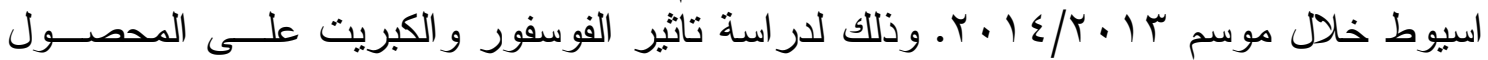

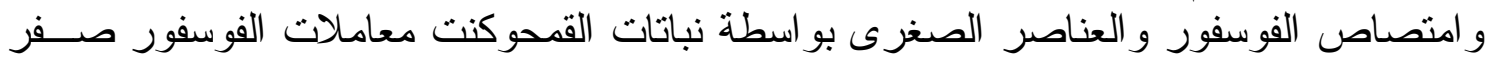

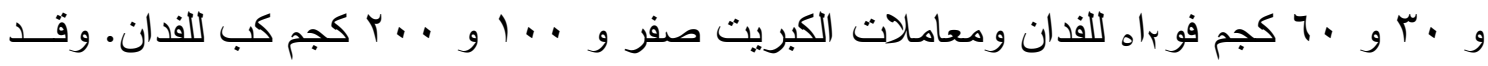

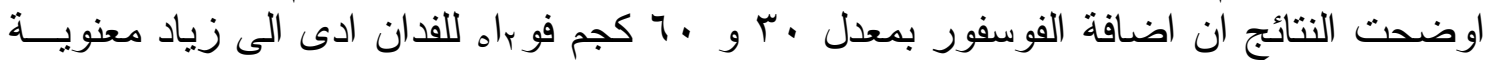

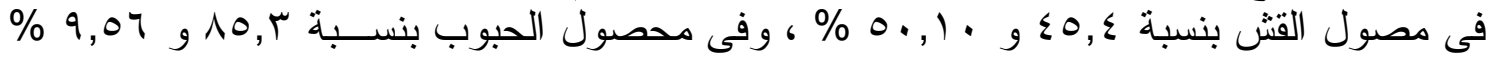

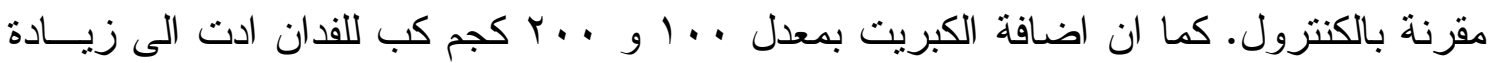

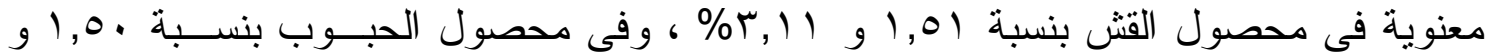

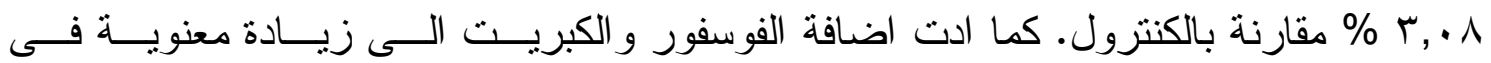

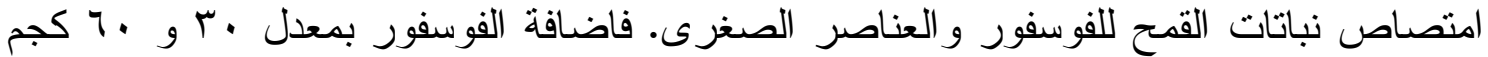

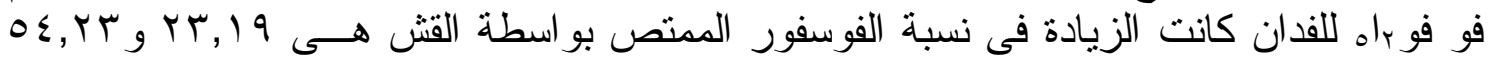

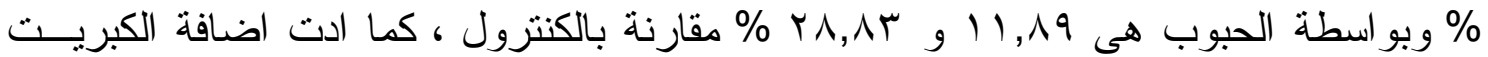

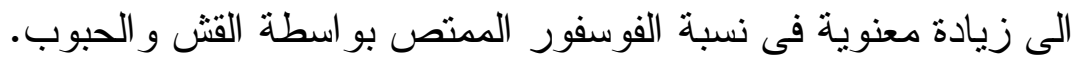

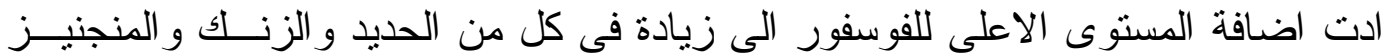

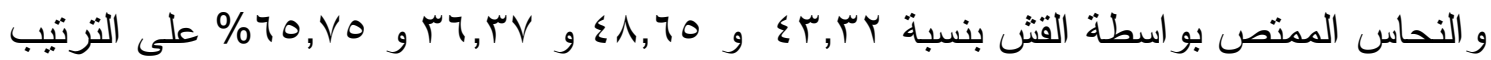

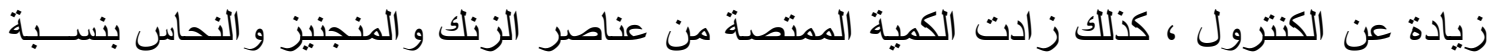

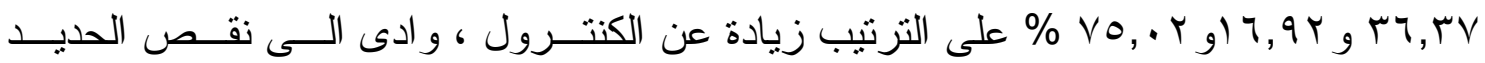

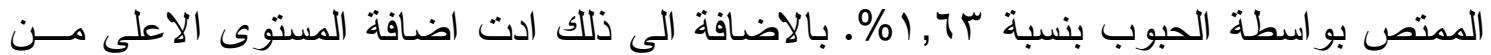

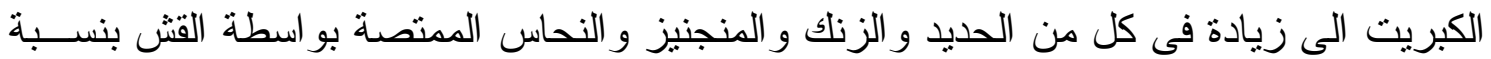

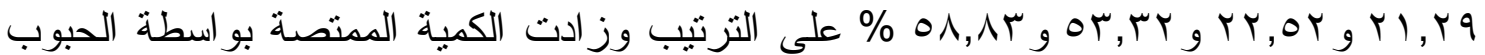

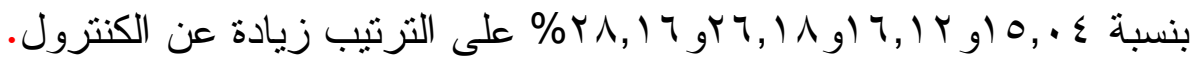

